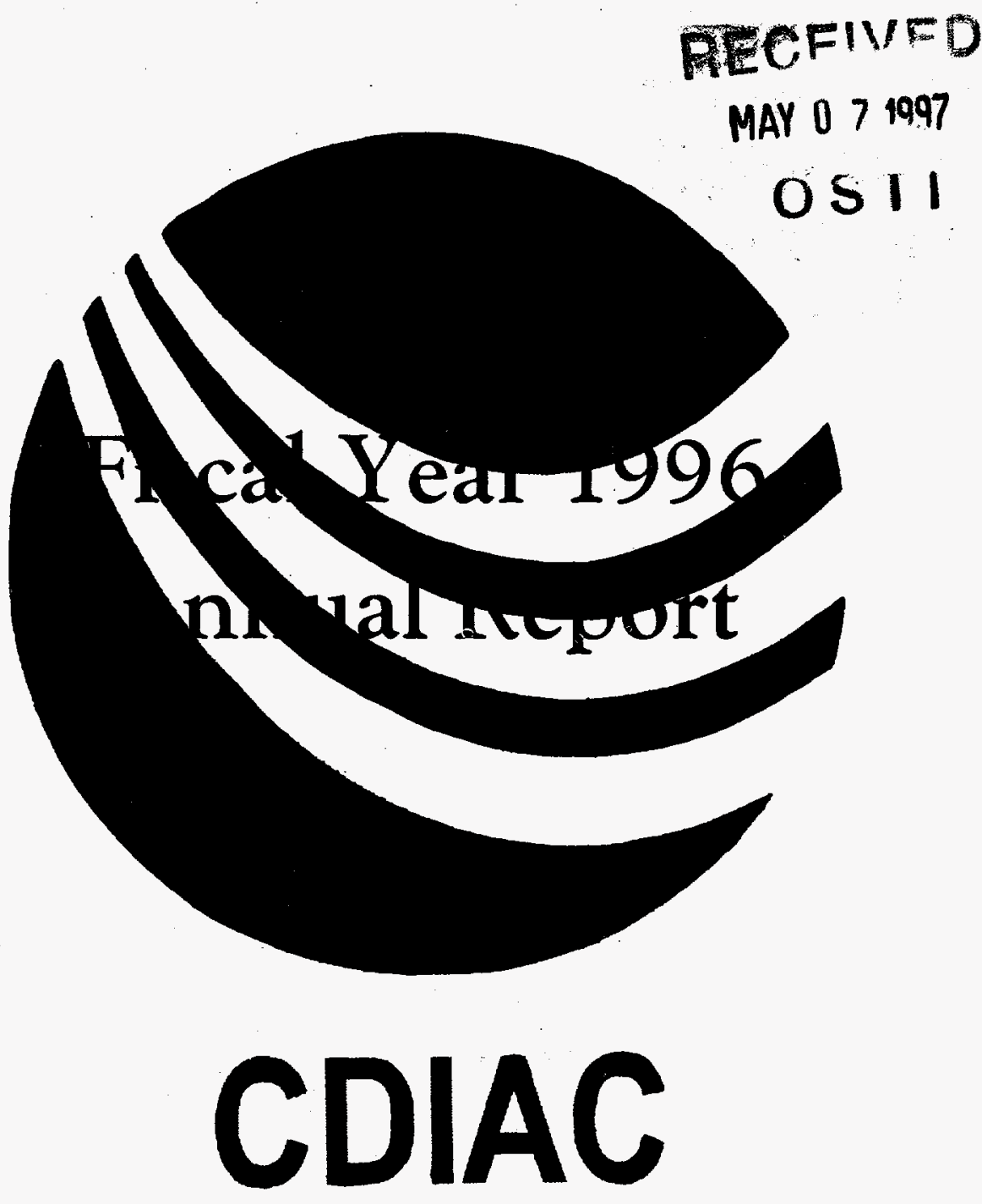

Carbon Dioxide Information Analysis Center World Data Center-A for Atmospheric Trace Gases

Environmental Sciences Division

Oak Ridge National Laboratory

February 1997 


\title{
Carbon Dioxide Information Analysis Center and World Data Center-A for Atmospheric Trace Gases
}

\author{
Fiscal Year 1996 \\ Annual Report
}

\author{
Robert M. Cushman, Thomas A. Boden, Sonja B. Jones, Dale P. Kaiser, and Tommy R. Nelson \\ Carbon Dioxide Information Analysis Center \\ Compiled by Marvel D. Burtis
}

Environmental Sciences Division

Publication No. 4625

Date Published: February 1997

Prepared for the

Global Change Research Program

Environmental Sciences Division

Office of Health and Environmental Research

U.S. Department of Energy

Budget Activity Number KP 1204010

Prepared by the

Carbon Dioxide Information Analysis Center

OAK RIDGE NATIONAL LABORATORY

Oak Ridge, Tennessee 37831-6335

managed by

LOCKHEED MARTIN ENERGY RESEARCH CORP.

for the

U.S. DEPARTMENT OF ENERGY

under contract DE-AC05-96OR22464 


\section{DISCLAIMER}

This report was prepared as an account of work sponsored by an agency of the United States Government. Neither the United States Government nor any agency thereof, nor any of their employees, make any warranty, express or implied, or assumes any legal liability or responsibility for the accuracy, completeness, or usefulness of any information, apparatus, product, or process disclosed, or represents that its use would not infringe privately owned rights. Reference herein to any specific commercial product, process, or service by trade name, trademark, manufacturer, or otherwise does not necessarily constitute or imply its endorsement, recommendation, or favoring by the United States Government or any agency thereof. The views and opinions of authors expressed herein do not necessarily state or reflect those of the United States Government or any agency thereof. 


\section{DISCLAMMER}

Portions of this document may be illegible in electronic image products. Images are produced from the best available original document. 


\section{Contents}

Introduction $\ldots \ldots \ldots \ldots \ldots \ldots \ldots \ldots \ldots \ldots \ldots \ldots \ldots \ldots \ldots \ldots \ldots$

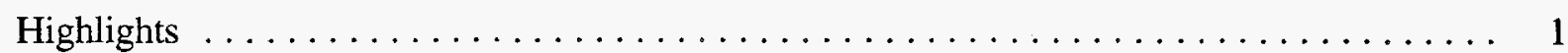

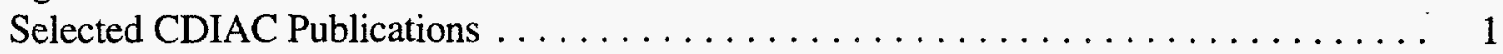

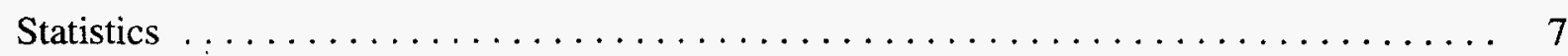

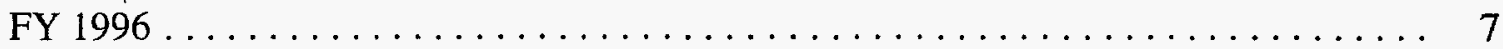

CDIAC's Most Requested World Wide Web Documents $\ldots \ldots \ldots \ldots \ldots \ldots \ldots \ldots$

Total Requests to Date $\ldots \ldots \ldots \ldots \ldots \ldots \ldots \ldots \ldots \ldots \ldots \ldots \ldots \ldots \ldots \ldots$

Selected CDIAC Citations $\ldots \ldots \ldots \ldots \ldots \ldots \ldots \ldots \ldots \ldots \ldots \ldots$

What's Coming in FY $1997 \ldots \ldots \ldots \ldots \ldots \ldots \ldots \ldots \ldots \ldots \ldots \ldots \ldots \ldots \ldots \ldots$

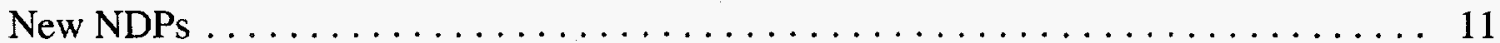

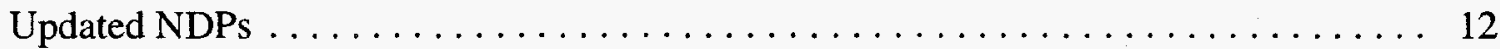

New Databases . . . . . . . . . . . . . . . . . . . . . . . 13

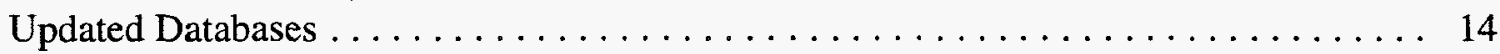

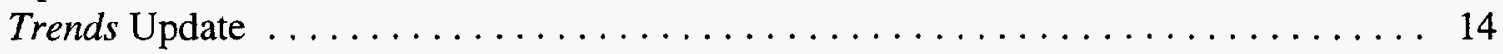

Additional CDIAC Publications, Presentations, and Awards $\ldots \ldots \ldots \ldots \ldots \ldots \ldots$

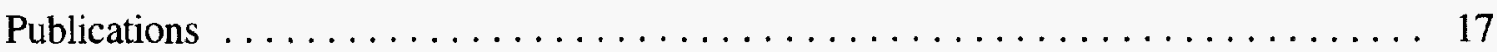

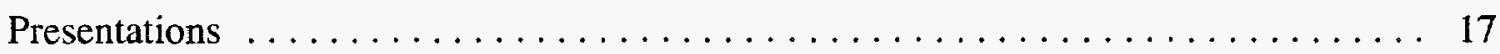

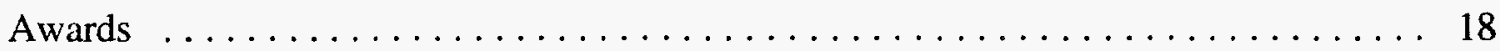

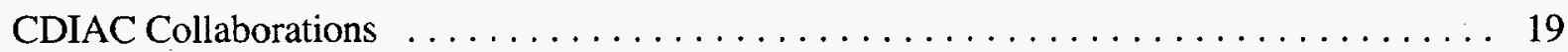

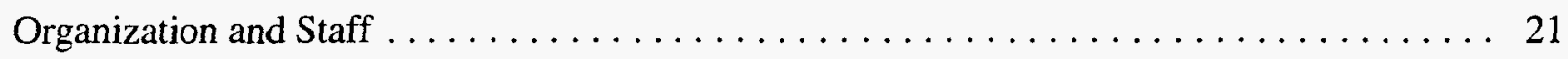

Acronyms and Other Abbreviations $\ldots \ldots \ldots \ldots \ldots \ldots \ldots \ldots \ldots \ldots \ldots \ldots \ldots \ldots$ 



\section{Introduction}

Fiscal year 1996 was especially productive for the Carbon Dioxide Information Analysis Center (CDIAC) at Oak Ridge National Laboratory (ORNL). If you look over the "Highlights" section in this report, you 'll notice a large number of new and updated data and information products that, I hope, will be useful to you.

During this past year, CDIAC witnessed a number of staff changes. Linda Allison and Antoinette Brenkert were welcomed into the Global Change Data group. The group is now led by Dale Kaiser, so that Tom Boden can handle our atmospheric databases. These moves strengthen our ability to produce the quality-assured and documented data products that are needed by the global-change community. Karen Gibson joined the User Services group, helping provide data and information products to our user community as efficiently and responsively as possible. Forrest Hoffman joined the Computing Systems group, taking on responsibility for enhancing the World Wide Web site that CDIAC maintains for the multiagency U.S. Global Change Data and Information System. At the end of the fiscal year 1996, Rich Daniels left us for a position with the State of Washington's Department of Ecology. We will miss his expertise with geographic information systems and issues related to land-use change and coastal vulnerability to rising sea level.

From our "Statistics" section, you'll see that, while the total number of requests from users continued to rise, the increase occurred primarily through our Web site. Currently we are making every possible effort to offer our products through the Web. We are striving to publish our numeric data packages, as well as such publications as our newsletter CDIAC Communications, on-line as soon as the printed versions are released, or possibly sooner. We have been assisted in our on-line efforts by Julie Watts, who helped put some of our classic printed reports (e.g., our glossaries and Trends) on the Web. I can assure you that we 're pedaling as fast as we can, while continuing to produce new data and information products that researchers and policymakers need.

I invite you to look through this report and see what we have been doing to serve the global-change community, as well as what we plan for fiscal year 1997.

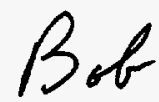

Robert M. Cushman 


\section{Highlights}

\section{Selected CDIAC Publications}

During the fiscal year (FY) 1996, the Carbon Dioxide Information Analysis Center (CDIAC) at Oak Ridge National Laboratory (ORNL) published eight numeric data packages (NDPs) under the auspices of the U.S. Department of Energy (DOE). The printed reports are available from CDIAC on request. The data and descriptive files are available via the Internet from CDIAC's anonymous file transfer protocol (FTP) area (cdiac.esd.ornl.gov) and from CDIAC's World Wide Web site (http://cdiac.esd.oml.gov), as well as on a variety of magnetic media.

- Atmospheric Carbon Dioxide Mixing Ratios from the NOAA Climate Monitoring and Diagnostics Laboratory Cooperative Flask Sampling Network, 1967-1993 (ORNL/CDIAC-73, NDP-005/R3). This revised NDP was contributed by Thomas Conway and Pieter Tans of the National Oceanic and Atmospheric Administration Climate Monitoring and Diagnostics Laboratory; it was prepared by CDIAC's Thomas Boden. NDP-005/R3 includes monthly averaged atmospheric $\mathrm{CO}_{2}$ mixing ratios from a global network of 40 land-based sites, and it includes shipboard measurements in the Pacific Ocean and South China Sea. The NDP includes 163 data files (approximately 60,000 individual flask $\mathrm{CO}_{2}$ measurements) and detailed documentation, including two reprints that offer greater detail about methods and analytical results. These measurements constitute the most geographically extensive, carefully calibrated, internally consistent atmospheric $\mathrm{CO}_{2}$ data set available and are essential for studies aimed at better understanding the global carbon cycle.

- United States Historical Climatology Network (U.S. HCN) Monthly Temperature and Precipitation Data (ORNL/CDIAC-87, NDP-019/R3). The data in this revised NDP were contributed by David Easterling, Thomas Karl, Elaine Mason, Pamela Hughes, and David Bowman of the National Climatic Data Center, and the NDP was prepared by CDIAC's Richard Daniels and Thomas Boden. NDP- 019/R3 documents a database containing monthly temperature and precipitation data for 1221 stations in the contiguous United States. These data, which for most stations extend through 1994, represent the best available data from the United States for analyzing long-term climate trends on a regional scale. The data have been adjusted to remove biases introduced by station moves, instrument changes, time-of-observation differences, and urbanization effects.

- Edited Synoptic Cloud Reports from Ships and Land Stations over the Globe, 1982-1991 (ORNL/CDIAC-77, NDP-026B). This NDP was contributed by Carole Hahn of the University of Arizona, Stephen Warren of the University of Washington, and Julius London of the University of Colorado; it was prepared by CDIAC's Laura Morris and Thomas Boden. NDP-026B includes 124 million reports from land stations and 15 million reports from ships, thus providing a 10-year global cloud data set. With this data set, a user can develop a climatology for any particular cloud type or group of types, for any geographical region, and at any spatial and temporal resolution. 
- Estimates of Global, Regional, and National $\mathrm{CO}_{2}$ Emissions from Fossil-Fuel Burning, Hydraulic Cement Production, and Gas Flaring: 1950-1992 (ORNL/CDIAC-58, NDP-030/R6). This revised NDP was prepared by Thomas Boden and Gregg Marland, Oak Ridge National Laboratory, and Robert Andres, University of Alaska, Fairbanks. In addition to $\mathrm{CO}_{2}$ emissions estimates through 1992, NDP-030/R6 includes the underlying data on energy production, consumption, and trade. For the first time, the methods for calculating $\mathrm{CO}_{2}$ emissions from gas flaring are presented. The data in NDP-030/R6 are useful in carbon cycle research and also for comparison with the greenhouse-gas emissions inventories prepared by individual countries in accordance with the Framework Convention on Climate Change. The data show that global emissions have grown almost four-fold since 1950 . However, the

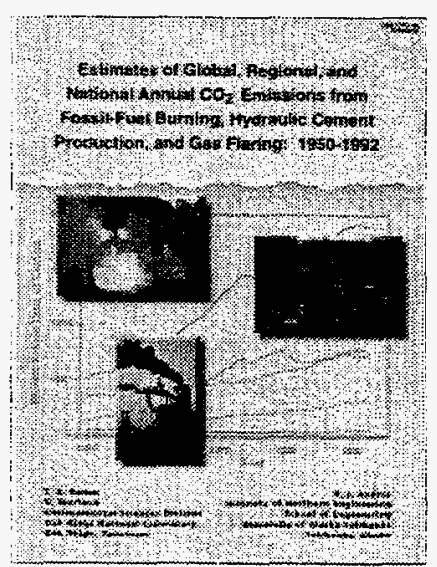
1992 total (6097 million metric tons of carbon) is $1.2 \%$ lower than the 1991 total (which included significant emissions of $\mathrm{CO}_{2}$ from the Kuwaiti oil fires) and ends a string of eight consecutive years of growth in global $\mathrm{CO}_{2}$ emissions. The United States, emitting 1332 million metric tons of carbon, continues to be the largest single source. Note: Data through 1994 were released by CDIAC in February 1997 (NDP-030/R7).

- Rattlesnake Mountain Observatory $\left(46.4^{\circ} \mathrm{N}, 119.6^{\circ} \mathrm{W}\right)$ Multispectral Optical Depth Measurements: 1979-1994 (ORNL/CDIAC-85, NDP-053). This NDP was contributed by Nels Larson of Pacific Northwest Laboratory (now Pacific Northwest National Laboratory), Joseph Michalsky of the Atmospheric Sciences Research Center, and Brock LeBaron of the Utah Bureau of Air Quality; it was prepared by CDIAC's Richard Daniels. NDP-053 includes data on optical depths for five wavelength bands measured in eastern Washington; the data are reported as total optical depths, total column aerosol optical depths, and tropospheric aerosol optical depths. These data are an important contribution to the scientific analysis of the role of aerosols in offsetting the warming effect of greenhouse gases in the atmosphere.

- Carbon Dioxide, Hydrographic, and Chemical Data Obtained in the Central South Pacific Ocean (WOCE Sections P17S and P16S) During the TUNES-2 Expedition of the RV Thomas Washington, July-August, 1991 (ORNL/CDIAC-86, NDP-054). This NDP was contributed by Taro Takahashi, John Goddard, Stephany Rubin, David Chipman, and Stewart Sutherland-(all of Lamont-Doherty Earth Observatory)—and by Catherine Goyet of Woods Hole Oceanographic Institution; it was prepared by CDIAC's Alexander Kozyr. NDP-054 includes data on total $\mathrm{CO}_{2}\left(\mathrm{TCO}_{2}\right)$, discrete partial pressure of $\mathrm{TCO}_{2}$, and total alkalinity (plus accompanying hydrographic and chemical data) during the TUNES Leg 2 Expedition, conducted as part of the World Ocean Circulation Experiment.

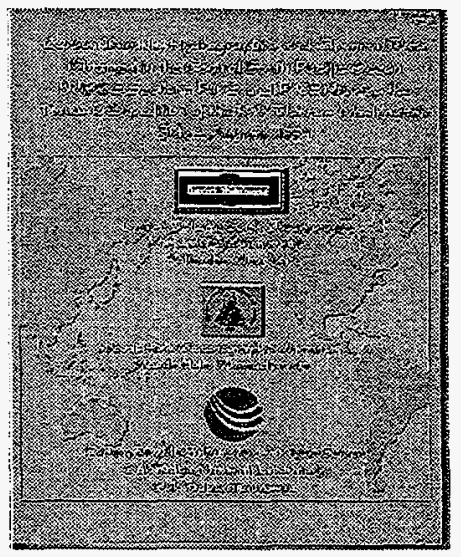

- Tropical Africa: Land Use, Biomass, and Carbon Estimates for 1980 (ORNL/CDIAC-92, NDP-055). This NDP was contributed by Sandra Brown and Greg Gaston of the U.S. Environmental Protection Agency; it was prepared by CDIAC's Richard Daniels. NDP-055 includes data on maximum potential aboveground biomass, land use, estimated actual biomass, and carbon in 1980, and it describes a methodology for extending the data to 1990 and beyond on the basis of population and land cover data. These data were collected to reduce the uncertainty associated with the possible magnitude of historical 
releases of carbon from land-use change. The data show, that in 1980, aboveground biomass averaged $209 \mathrm{Mg} / \mathrm{ha}$ in closed forests and $67 \mathrm{Mg} / \mathrm{ha}$ in open forests in comparison with the maximum potential aboveground biomass of 296 and $108 \mathrm{Mg} /$ ha in closed and open forests, respectively.

- Carbon Dioxide, Hydrographic, and Chemical Data Obtained During the R/V Meteor Cruise 18/1 in the North Atlantic Ocean (WOCE Section A1E, September 1991) (ORNL/CDIAC-91, NDP-056). This NDP was contributed by Kenneth Johnson and Douglas Wallace of Brookhaven National Laboratory; Bernd Schneider of the Institut für Ostseeforschung; and Lutger Mintrop of the Institut für Meereskunde; it was prepared by CDIAC's Alexander Kozyr. NDP-056 includes data on total $\mathrm{CO}_{2}\left(\mathrm{TCO}_{2}\right)$, discrete partial pressure of $\mathrm{CO}_{2}$, and total alkalinity (plus accompanying hydrographic and chemical data) during the September 1991 cruise of the German Research Vessel Meteor, conducted as part of the World Ocean Circulation Experiment. The cruise began in Reykjavik, Iceland, and ended in Hamburg, Germany. The North Atlantic is important in global climate-change studies both because of exchange of $\mathrm{CO}_{2}$ between the atmosphere and the ocean and because of the North Atlantic's unique role in deep water formation.

In addition, CDIAC published the following four on-line databases, which are available in electronic form from CDIAC's anonymous FTP area (cdiac.esd.ornl.gov) and the CDIAC World Wide Web site (http://cdiac.esd.ornl.gov) as well as on a variety of magnetic media that can be ordered from CDIAC.

- Global and Latitudinal Estimates of $\delta 13 C$ from Fossil-Fuel Consumption and Cement Manufacture (CDIAC/DB1013). This numeric database was contributed by Robert J. Andres of the University of Alaska, Fairbanks; Gregg Marland of Oak Ridge National Laboratory; and Steve Bischof of Connecticut College. It was prepared by CDIAC's Thomas Boden. The database contains estimates of the annual mean value of $\delta^{13} \mathrm{C}$ of $\mathrm{CO}_{2}$ emissions from fossil-fuel combustion and cement manufacture for 1860-1992 and the value of $\delta^{13} \mathrm{C}$ for $1^{\circ}$ - latitude bands for the years 1950, 1960, 1970, 1980, 1990, 1991, and 1992. The estimates account for the changing mixes of (a) coal, petroleum, and natural gas being consumed and (b) petroleum from various producing areas. The time series provides an additional constraint for balancing the sources and sinks of the global carbon cycle. The on-line database consists of a descriptive file as well as data files containing the global annual estimates and $1^{\circ}$ latitudinal means of $\delta^{13} \mathrm{C}$ for fossil-fuel $\mathrm{CO}_{2}$ emissions.

- In Situ Carbon-13 and Oxygen-18 Ratios of Atmospheric $\mathrm{CO}_{2}$ from Cape Grim, Tasmania, Australia: 1982-1993 (CDIAC/DB1014). This numeric database was contributed by Roger Francey, Colin Allison, Emily Welch, Ian Enting, and Helen Goodman of the Commonwealth Scientific and Industrial Research Organisation, Australia, and was prepared by CDIAC's Thomas Boden. This record is possibly the most accurate representation of global atmospheric ${ }^{13} \mathrm{C}$ behavior over the past decade and may be used to partition the uptake of fossil-fuel carbon emissions between ocean and terrestrial plant reservoirs.

- Global Patterns of Carbon Dioxide Emissions from Soils on a 0.5-Degree Grid Cell Basis (CDIAC/DB1015). This numeric database was contributed by James Raich of Iowa State University and Christopher Potter of National Aeronautics and Space Administration's Ames Research Center and prepared by CDIAC's Antoinette Brenkert. The database contains global, spatially explicit $\left(0.5^{\circ}\right.$ grid cells) and temporally explicit (monthly and annual) model-derived estimates of soil $\mathrm{CO}_{2}$ emissions from the respiration of soil organisms and plant roots. Carbon fluxes from soil are an important component of the global carbon cycle; the quantification of such fluxes is necessary to understand the relationship between anthropogenic carbon emissions and atmospheric concentrations of $\mathrm{CO}_{2}$, the single most important greenhouse gas. 
- Global Population Distribution (1990), Terrestrial Area and Country Name Information on a One by One Degree Grid Cell Basis (CDIAC/DB1016). This numeric database was contributed by Yi-Fan Li Canadian Global Emissions Inventory Centre, Atmospheric Environment Service, Environment Canada, and was prepared by CDIAC's Antoinette Brenkert. The database contains gridded information on the worldwide distribution of population for 1990; country-specific information on the percentage of a country's population present in each grid cell, the percentage of a country's total area in a grid cell, and the country's percentage of the grid cell that is terrestrial; the latitude and longitude coordinates of each grid cell; a grid code number (which is a translation of the latitude or longitude value and is used in the Global Emission Inventory Activity databases), the country or region's name; and the.United Nations' three-digit country code that represents that name. Accurate population data are important, in general, for understanding the relationship between society and environmental factors and for specific applications such as estimating the spatial distribution of $\mathrm{CO}_{2}$ emissions from country-level statistics.

CDIAC also published the following:

- Selected Translated Abstracts of Russian-Language Climate-Change Publications. III: Aerosols (ORNL/CDLAC-88; Proceedings of the Research Institute of Hydrometeorological Information-World Data Center, Issue 164). The third volume in a series on Russian climatechange research, this report includes 102 side-by-side Russian and English abstracts relevant to the influence of aerosols on climate. Aerosols are now considered to off-set a significant portion of the global warming that might result from increased atmospheric concentrations of greenhouse gases. The first two volumes in the series focused on the surface energy budget and clouds. Note: A fourth volume, on the topic of general circulation models, was published by CDIAC in October 1996. Produced under the auspices of a 1972 U.S.-U.S.S.R. agreement on protection of the environment, the series opens up to Western

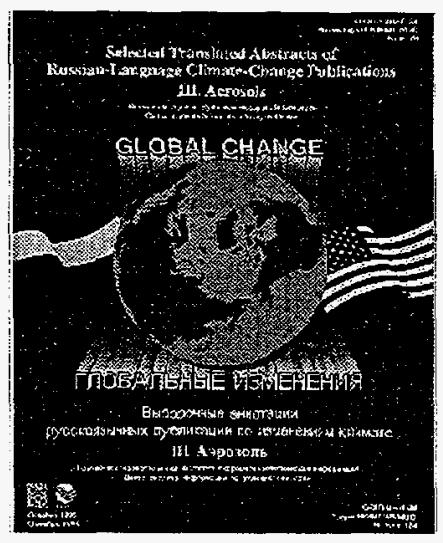
researchers a wealth of climate-change literature that has previously been available only in Russian.

- Two issues in the DOE Research Summary series:

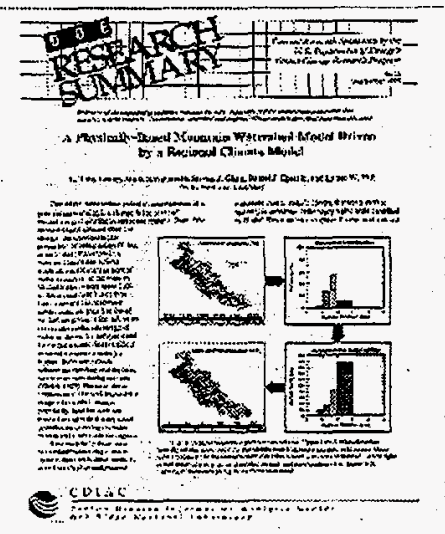
A Physically-Based Mountain Watershed Model Driven by a Regional Climate Model by Ruby Leung, Mark Wigmosta, Steven Ghan, Daniel Epstein, and Lance Vail of Pacific Northwest Laboratory (now Pacific Northwest National Laboratory). Estimates of the impact of greenhouse warming on water resources require physically based rather than empirically based models. Issue 32 in the DOE Research Summary series describes an innovative approach of coupling mountain watershed and regional climate models. 
The Visualization and Computation System (VCS) Uniquely Versatile Software by Dean Williams, Robert Mobley, Robert Drach, and Thomas Phillips of DOE's Lawrence Livermore National Laboratory. Issue 33 in the DOE Research Summary series describes software developed by the Program for Climate Model Diagnosis and Intercomparison for selecting, manipulating, and displaying of scientific data. The VCS user gains virtually complete control of the appearance of the data display and associated text and animation by specifying the desired data, the graphics method, and the display template. This control is especially important in the study of disagreements between complex climate models and those between models and observations. Issue 33 is also

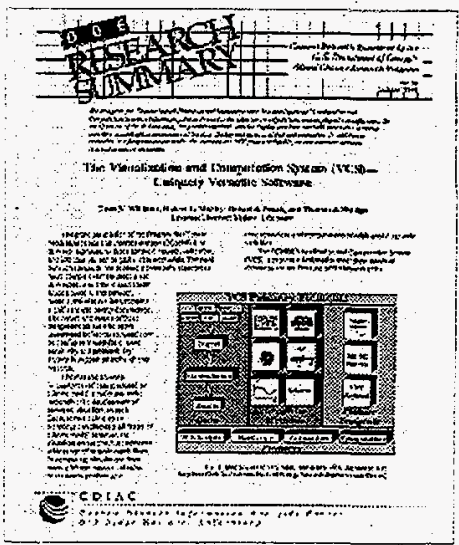
available on-line from CDIAC's World Wide Web Home Page (http://cdiac.esd.ornl.gov).

- Two issues of the newsletter CDIAC Communications, which are available on-line from CDIAC's World Wide Web home page (http://cdiac.esd.ornl.gov), and in print on request.

Issue 21 (Fall 1995) featured a lead story about modeling land-use change. In addition, it highlighted recent issues of the DOE Research Summary series; described seven new numeric data packages, six other new data sets, and eight new reports available from CDIAC; and announced the availability of other services and publications related to global change.

Issue 22 (Spring 1996) featured a lead story about DOE's global survey of $\mathrm{CO}_{2}$ in the oceans and highlighted recent issues in the DOE Research Summary series. It also described five new numeric data packages, three other new data sets, and various reports available from CDIAC, and it announced the availability of other services and publications related to global change.

- On behalf of DOE, CDIAC produced a brochure for the Global Change Data and Information System (GCDIS), whose purpose is to manage and archive data and information resulting from the U.S. Global Change Research Program (USGCRP). The brochure describes both the USGCRP and GCDIS, listing the types of information available from GCDIS and potential users of the information. It names the GCDIS participating agencies and provides information about how to access the GCDIS home page, the GCDIS Gopher, the Global Change Master Directory, the USGCRP office, and the U.S. Global Change Research Information Office. 



\section{Statistics}

\section{FY 1996}

- Over 16,520 unique systems accessed CDIAC's World Wide Web site, viewing over 423,620 files.

- CDIAC's anonymous file transfer protocol (FTP) area was accessed by 3,995 systems retrieving over 51,550 files.

- CDIAC responded to 4,782 traditional requests (i.e., mail, fax, phone, personal communication, and e-mail) for data and information from 2,052 individuals in 75 countries; in responding, CDIAC distributed 4,100 copies of NDPs, computer model packages, databases, DOE reports, CDIAC reports, and other materials.

- CDIAC's Directory of Global Change Researchers and Policymakers consists of approximately 10,000 individuals, agencies, and institutions representing 157 countries.

\section{CDIAC 's Most Requested World Wide Web Documents}

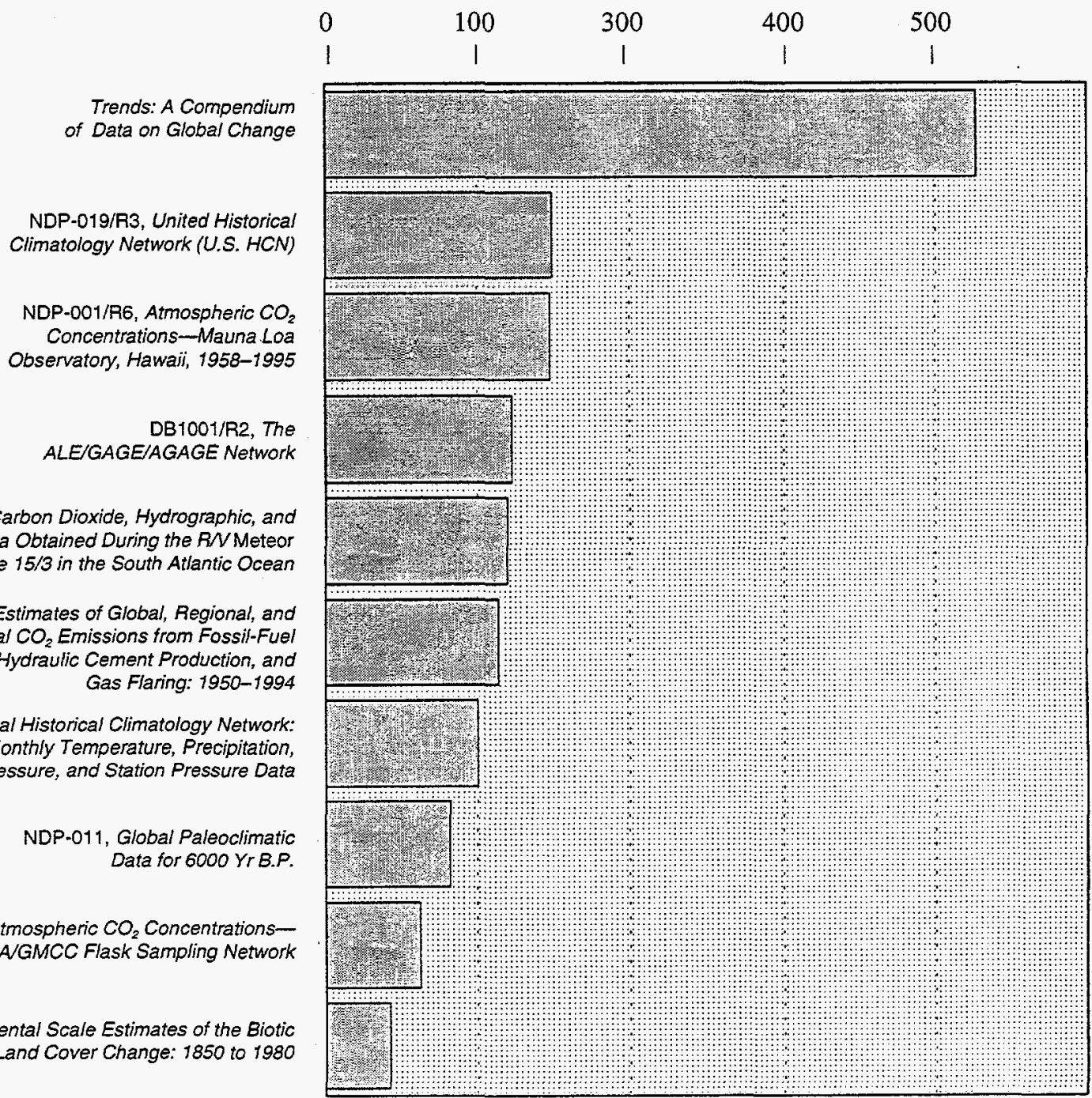


Total of 92,832 requests for FY 1985 through FY 1996!

Thousands

30

25

20

15

10

5

0

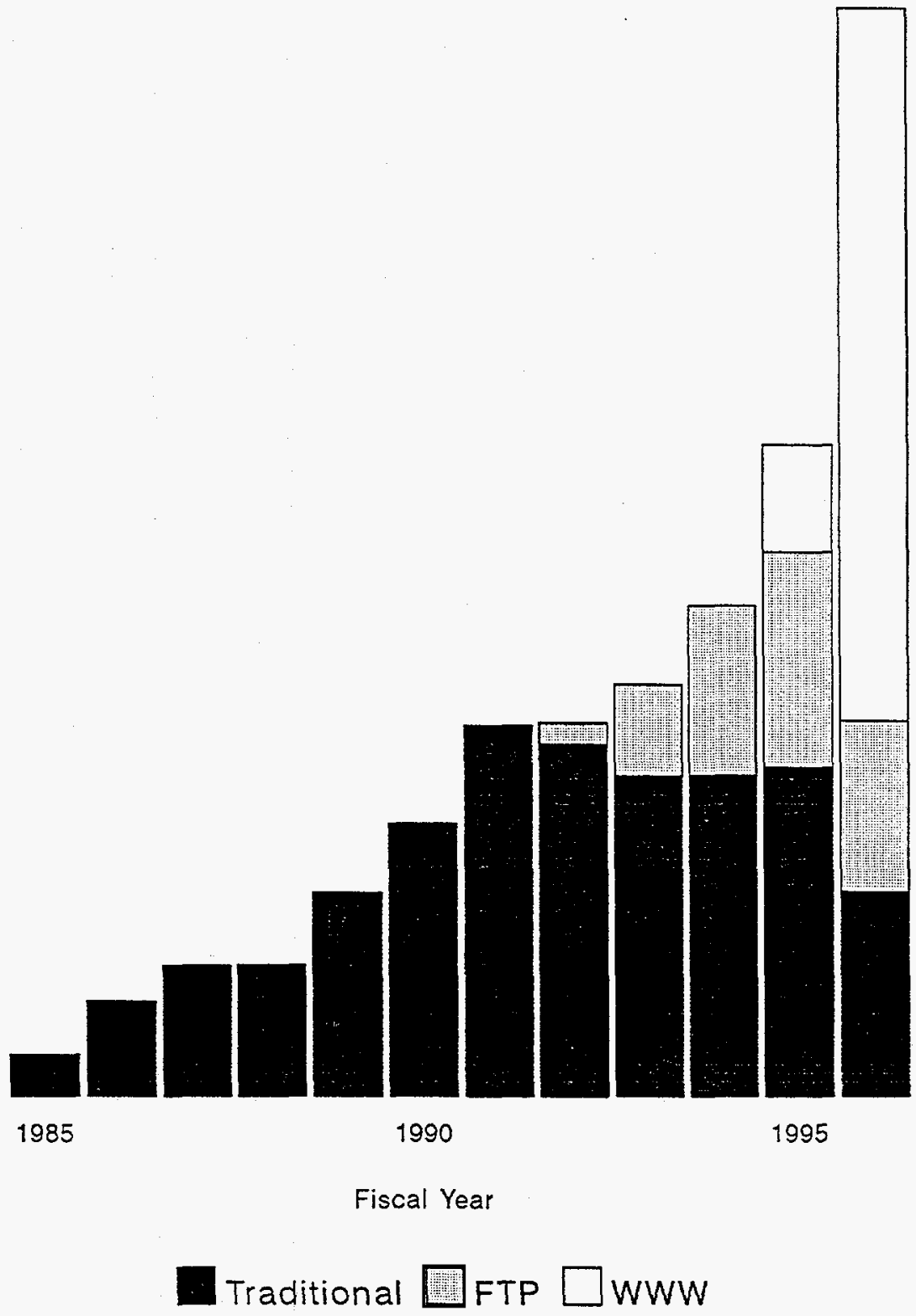




\section{Selected CDIAC Citations}

Data from CDIAC publications were cited in a number of journal articles, magazine articles, and newsletters. The following publications are representative of works that have been cited.

- NDP-019/R3, United States Historical Climatology Network (U.S. HCN),

cited in Karl, T. R., R. W. Knight, and N. Plummer. 1995. Trends in high-frequency climate variability in the twentieth century. Nature 377:217-20.

- NDP-030/R6, Estimates of Global, Regional, and National Annual $\mathrm{CO}_{2}$ Emissions from Fossil-Fuel Burning, Hydraulic Cement Production, and Gas Flaring: 1950-1992

cited in Doyle, R. 1996. Carbon Dioxide Emissions. Scientific American 274:24.

cited in Anonymous. 1996. Global Warming. Consumer Reports,. Sept. 1996, p. 39.

- NDP-040, Daily Temperature and Precipitation Data for 223 USSR Stations

cited in Jones, P. D., and K. R. Briffa. 1995. Growing season temperatures over the former Soviet Union. International Journal of Climatology 115:943-59.

- NDP-050, Continental Scale Estimates of the Biotic Carbon Flux from Land Cover Change: 1850 to 1980 cited in Houghton, R. A. 1995. Land-use change and the carbon cycle. Global Change Biology 1:275-87.

- ORNL/CDIAC-65, Trends 93: A Compendium of Data on Global Change

cited in Amthor, J. S. 1995. Terrestrial higher-plant response to increasing atmospheric $\mathrm{CO}_{2}$ in relation to the global carbon cycle. Global Change Biology 1:243-74.

cited in Anonymous. 1996. Butterfly Flap Revisited. World Climate Report 2:3.

cited in Battle, M., M. Bender, T. Sowers, P. P. Tans, J. H. Butler, J. W. Elkins, J. T. Ellis, T. Conway, N. Zhang, P. Lang, and A. D. Clarke. 1996. Atmospheric gas concentrations over the past century measured in air from firn at the South Pole. Nature 383:231-235.

- DOE/NBB-0091T (TR055), Climate Data Bases of the People's Republic of China, 1841-1988

cited in Wai, M. M.-K., P. T. Walsh, and W.-M. Ma. 1995. The timing and distribution of summer convective rainfall over Hong Kong and South China. Bulletin of the Hong Kong Meteorological Society 5:3-23. 



\section{What's Coming in FY 1997}

CDIAC is working on the following new or updated NDPs and hopes to have them available (both in printed format and on-line) in FY 1997:

New NDPs

- NDP-043C

A Coastal Hazards Data Base for the U.S. West Coast (Contributors: T. W. Beaty, ORNL; V. Gornitz, Goddard Institute for Space Studies. This is the third and last of a series of NDPs that document the coastal hazards database developed by CDIAC in cooperation with Vivien Gornitz. The documentation of this NDP is currently undergoing final editing.

- NDP-057

Carbon-14 Measurements in Atmospheric $\mathrm{CO}_{2}$ from Northern and Southern Hemisphere Sites, 1962-1993 (Contributors: R. Nydal and K. Lövseth, the Norwegian Institute of Technology ). This database was completed in early FY 1997 and provides ${ }^{14} \mathrm{C}$ measurements from Dakar, Senegal; Debre Zeit, Ethiopia; Fruholmen, Gråkallen, Kapp Linné, Lindesnes, and Vassfjellet, Norway; Fianarantsoa, Madagascar; Izaña and Mas Palomas, Canary Islands; Rehovot, Israel; Santiago de Compostela, Spain; and N Djamena, Chad. This database represents the most geographically extensive atmospheric ${ }^{14} \mathrm{C}$ data set available. Documentation was published in November 1996.

- NDP-058

Geographic Patterns of Carbon Dioxide Emissions from Fossil-Fuel Burning, Hydraulic Cement Production, and Gas Flaring on a One Degree by One Degree Grid Cell Basis: 1950 to 1990 (Contributors: R. Andres, University of Alaska-Fairbanks, and G. Marland, ORNL; I. Fung, University of Victoria; and E. Matthews, Goddard Institute for Space Studies). The data have been assembled in connection with the Global Emissions Inventory Activity, a component of International Global Atmospheric Chemistry/International Geosphere-Biosphere Programme. Country-level $\mathrm{CO}_{2}$ emissions (NDP-030/R6) for 1950, 1960, 1970, 1980, and 1990 have been distributed on a $1^{\circ} \times 1^{\circ}$ latitude and longitude grid within countries using a $1^{\circ}$ matrix of population data from the Goddard Institute for Space Studies. The documentation of this NDP is currently undergoing final editing.

- NDP-059

Daily Snow Depth Measurements from 195 Stations in the United States [Contributors: D. R. Easterling, P. Jamason, D. P. Bowman, P. Y. Hughes, and E. H. Mason, National Climatic Data Center (NCDC)]. This NDP will contain daily snow depth measurements for 195 National Weather Service first-order climatological stations in the United States. The data were assembled and made available by the NCDC. The 195 stations encompass 388 unique sampling locations in 48 of the 50 states; no observations from Hawaii or Delaware are included in the database. The earliest observations date back to 1893, and data for many stations extend through 1992 . This NDP was published in March 1997.

- NDP-060

Carbon Dioxide Hydrographic, and Chemical Data Obtained During the $R / V$ Thomas Washington Cruise TUNES-3 in the Equatorial Pacific Ocean (WOCE section P16C) (Contributors: C. Goyet, Woods Hole Oceanographic Institution, and P. R. Guenther, C. D. Keeling, and L. D. Talley, Scripps Institution of Oceanography). This data documentation discusses the procedures and methods used to obtain total $\mathrm{CO}_{2}\left(\mathrm{TCO}_{2}\right)$, total alkalinity (TALK), hydrographic, and chemical data during the Research Vessel Thomas Washington Expedition TUNES-3 in the Equatorial Pacific Ocean (Section P16C). Documentation was published in December 1996.

- NDP-061 Effects of $\mathrm{CO}_{2}$ and Nitrogen Fertilization on Vegetation Nutrient Content in Juvenile Ponderosa Pine (Contributors: D. W. Johnson, J. T. Ball, and R. F. Walker, Desert Research Institute and University of Nevada). This NDP presents measured values of plant growth and nutrient (nitrogen, phosphorus, sulfur, potassium, calcium, magnesium, boron, copper, iron, 
manganese, and zinc) concentration and content from a study of the effects of $\mathrm{CO}_{2}$ and nitrogen fertilization on ponderosa pine conducted in open-top chambers in Placerville, California.

Carbon Dioxide, Hydrographic, and Chemical Data Obtained During the $R / V$ Thomas Washington Cruise TUNES-1 in the Equatorial Pacific Ocean (WOCE Section P17C) (Contributors: Catherine Goyet et al., Woods Hole Oceanographic Institution). This NDP will discuss the procedure and methods used to obtain total $\mathrm{CO}_{2}\left(\mathrm{TCO}_{2}\right)$, total alkalinity (TALK), and hydrographic and chemical data during the Research Vessel Thomas Washington Expedition TUNES-1 in the Equatorial Pacific Ocean (Section P17C). The cruise began in San Diego, California, on May 31, 1991, and finished in Papeete, Tahiti, on July 11, 1991. the Southern Ocean February-April 1992 (Contributors: D. W. Chipman et al., LamontDoherty Earth Observatory; and M. K. Koshlyakov, Shirshov Institute of Oceanography). This NDP will summarize the results of $\mathrm{CO}_{2}$ and associated hydrographic measurements made along the WOCE S4P section located near $67^{\circ} \mathrm{S}$ between $73^{\circ} \mathrm{W}$ and $172^{\circ} \mathrm{E}$ in the Pacific sector of the Southern Ocean. The expedition was carried out aboard the Russian Research Vessel Akademik Ioffe from period February 14 through April 6, 1992.

- NDP-XX

Atmospheric and Sea Surface Underway Measurements of Partial Pressure of $\mathrm{CO}_{2}\left(\mathrm{p} \mathrm{CO}_{2}\right)$ in the Indian Ocean During WOCE Cruises 1994-1996. (Contributors: Chris Sabine et al., Princeton University). This NDP will discuss the procedure and methods used to obtain underway $\mathrm{pCO}_{2}$ data on 9 WOCE cruises conducted aboard the $\mathrm{R} / \mathrm{V}$ Knorr in the Indian Ocean during 1994-1996.

- NDP-XX

Tropical Southeast Asia: Land Cover and Biomass-Carbon Estimates for 1980 (Contributors: S. Brown, A. Prasad, and D. Liu, University of Illinois, and Louis Iverson, U.S. Forest Service). This is the fourth database to be published by CDIAC concerning carbon fluxes to the atmosphere from tropical land-use changes. The database consists of estimates of geographically referenced carbon densities of forest soils and vegetation in tropical Asia. The vegetation carbon densities are based on potential carbon estimates, which are derived from climatic, edaphic and geomorphic indices and vegetation and are subsequently modified on the basis of population densities, climate, and vegetation data. The soil organic carbon estimates are calculated from pedon data for tropical forests and mapped to a texture/climate map for all of tropical Asia.

Updated NDPs

- NDP-001/R7

Atmospheric $\mathrm{CO}_{2}$ Concentrations and ${ }^{13} \mathrm{C} / C^{12}$ Ratios from Mauna Loa Observatory, Hawaï: 1958-1996 (Contributors: D. Keeling and T. Whorf, Scripps Institution of Oceanography). This NDP will update two of the most significant global-change atmospheric carbon records of modern time. Monthly and annual updates through 1996 will be provided for Keeling and Whorf's popular atmospheric $\mathrm{CO}_{2}$ mixing ratio record from Mauna Loa, the longest continuous record of atmospheric $\mathrm{CO}_{2}$ available in the world. In addition, this update will include Keeling's record of atmospheric ${ }^{13} \mathrm{C} / \mathrm{C}^{12}$ ratios from Mauna Loa, hitherto presented only in graphs in published literature. This record dates back to the mid-1970s and includes carbon isotope ratio measurements through 1996 . This isotopic record helps studies attempting to discern and quantify anthropogenic and natural sources of atmospheric $\mathrm{CO}_{2}$.

- NDP-030/R7

Estimates of Global, Regional, and National Annual $\mathrm{CO}_{2}$-Emissions from Fossil-Fuel Burning, Hydraulic Cement Production, and Gas Flaring: 1950-1994 (Contributors: G. Marland and T. Boden, ORNL). This NDP was completed early in FY 1997 and documents the most comprehensive $\mathrm{CO}_{2}$-emissions data set available. The database includes global, regional, and national annual estimates of $\mathrm{CO}_{2}$ emissions resulting from fossil-fuel burning, 
cement manufacturing, and gas flaring in oil fields for 1950-1994, as well as the energy production, consumption, and trade data used in making these estimates. This documentation was published in February 1997.

- NDP-039/R1

Two Long-Term Instrumental Climatic Data Bases of the People's Republic of China (Contributors: S. Tao, C. Fu, Z. Zeng, and Q. Zhang, Chinese Academy of Sciences). The Chinese Academy of Sciences has provided CDIAC with updates through 1993 of the monthly climate records contained in these databases. The original 60 -station database has been expanded to include data from 65 stations.

- NDP-042/R1

U.S. Historical Climatology Network (HCN) Daily Temperature and Precipitation Data (Contributors: D. R. Easterling, T. R. Karl, E. H. Mason, P. Y. Hughes, and D. P. Bowman, National Climatic Data Center).These data are made available by the National Climatic Data Center. They have been updated through 1994 and expanded to include not only the 138 stations in the original version of NDP-042 but also most of the remaining stations in the HCN, for a total of 1062 stations. This database is sure to be one of the most valuable climate resources available for the United States.

- NDP-048/R1 Six-and Three-Hourly Meteorological Observations from 223 U.S.S.R. Stations (Contributors: V. N. Razuvayev, E. G. Apasova, and R. A. Martuganov, All-Russian Research Institute of Hydrometeorological Information). The All-Russian Research Institute of Hydrometeorological Information-World Data Center, in Obninsk, Russia, has provided CDIAC with updates of 3-hourly data extending the database's period of record from the mid-1980s through 1990.

New Databases

- Global Population Distribution (1990), Terrestrial Area, and Country Name Information on a One by One Degree Grid Cell Basis (DB1016). (Contributor: Yi-F. Li, Environment Canada). This database contains gridded information on the worldwide distribution of population for 1990 and country-specific information on the percentage of the countries population in each grid cell. This database was completed in early 1997, and it is the most recent update available of the geographic distribution of population in gridded format.

- Northern Hemisphere Biome- and Process-Specific Changes in Forest Area and Gross Merchantable Volume: 1890-1990 (DB1017) (Contributors: A. N. D. Auclair, J. A. Bedford, and C. Revenga, Science Policy Associates, Inc. of Washington, D.C.). The database consists of annual values of the areal extent (ha) and gross merchantable wood volume $\left(\mathrm{m}^{3}\right)$ of forest accrual processes in the Northern Hemisphere boreal and temperate forests from 1890 to 1990 . The data files cover the following biomes separately for each of six geographic regions (Alaska, Canada, Europe, former Soviet Union, non-Soviet temperate Asia, and the contiguous United States); forest tundra, boreal softwoods, mixed hardwoods, temperate softwoods, temperate hardwoods, and temperate wood- and shrublands. This database was completed in early 1997.

We also hope to publish the following databases in the CDIAC DB series on-line during FY 1997 :

- Atmospheric Halocarbon Records from the NOAA/CMDL Flask Sampling Program (Contributors: J. Elkins et al., Climate Monitoring and Diagnostics Laboratory). This database will offer chlorofluorocarbon (CFC-11 and CFC-12) and halocarbon (HCFC-22, H-1301, and H-1211) records from seven National Oceanic and Atmospheric Administration/Climate Monitoring and Diagnostics Laboratory flask sampling sites. The sites will include Niwot Ridge, Colorado; Mauna Loa, Hawaii; Point Barrow, Alaska; American Samoa; the South Pole; Alert, Northwest Territories, Canada; and Cape Grim, Tasmania. This database will offer records through 1995, including monthly values and measurements from individual flask samples. 
- Carbon Isotopes in Atmospheric Carbon Dioxide from Schauinsland, Germany and Vermunt, Austria (Contributor: I. Levin, University of Heidelberg). This database will offer long-term $\Delta^{13} \mathrm{C}$ and ${ }^{14} \mathrm{C}$ records from Schauinsland, Germany, and Vermunt, Austria. The records date back to 1959 for Vermunt and back to 1976 for Schauinsland, thus providing two of the longest continuous carbon isotope records from Europe.

- Carbon Isotopes in Atmospheric Carbon Dioxide from Wellington, New Zealand (Contributor: M. Manning, National Institute of Water and Atmospheric Research). This database will offer ${ }^{14} \mathrm{C}$ and $\Delta^{14} \mathrm{C}$ measurements dating back to 1954 from Wellington, New Zealand. This database constitutes the longest isotopic carbon record in the Southern Hemisphere.

- Global Sulfur Emissions on a One Degree by One Degree Grid Cell Basis: 1985 and 1990 (Contributor: C. Benkovitz, Brookhaven National Laboratory). The data pertain to anthropogenic emissions, naturally occurring emissions from oceans, and volcanic emissions. The data were collected to provide data support to Global Change Assessment Research-that is the integrated assessment research community and others-and are being made available in collaboration with the Global Emissions Inventory Activity of the International Geosphere-Biosphere Programme.

- Meta-analytic Review and Synthesis of Vegetation Responses to Elevated Atmospheric $\mathrm{CO}_{2}$ (Contributor: P. Curtis, The Ohio State University). This database will be a comprehensive digital database of all vegetation $\mathrm{CO}_{2}-$ response results published to date. The results will be integrated and synthesized by using meta-analytic methods and will focus on two general lines of inquiry: (1) determining the magnitude and significance of the $\mathrm{CO}_{2}$ response for a number of physiological and growth parameters and (2) analyzing how environmental factors or partitioning among functional groups affects the magnitude of physiological and growth responses to elevated levels of $\mathrm{CO}_{2}$.

\section{Updated Databases}

- Measurements from the ALE/GAGE/AGAGE Network (Contributors: R. Prinn, Massachusetts Institute of Technology, et al.). Measurements from the ALE/GAGE instruments were updated in early FY 1997. Measurements from the AGAGE instruments will be made available later in FY 1997. This database offers continuous highfrequency gas chromatographic measurements dating back to 1978, for two biogenic/anthropogenic gases [(methane $\left(\mathrm{CH}_{4}\right)$ and nitrous oxide, $\left(\mathrm{N}_{2} \mathrm{O}\right)$ ] and five anthropogenic gases [chlorofluorocarbons $\left(\mathrm{CFCl}_{3}, \mathrm{CF}_{2} \mathrm{Cl}_{2}\right.$, and $\mathrm{CF}_{2} \mathrm{ClCFCl}$ ), methyl chloroform $\left(\mathrm{CH}_{3} \mathrm{CCl}_{3}\right)$, and carbon tetrachloride $\left.\left(\mathrm{CCl}_{4}\right)\right]$ from globally distributed sites. The current station locations are Cape Grim, Tasmania; Point Matatula, American Samoa; Ragged Point, Barbados; Trinidad Head, California; and Mace Head, Ireland. Stations also previously existed at Cape Meares, Oregon, and Adrigole, Ireland.

- Carbon-13 and Oxygen-18 Isotopes from Cape Grim, Tasmania (Contributor, R. J. Francey, Commonwealth Scientific and Industrial Research Organisation). This updated database will offer ${ }^{13} \mathrm{C}$ and ${ }^{18} \mathrm{O}$ isotope measurements through 1996 from Cape Grim, Tasmania. These measurements are made through in situ extraction of $\mathrm{CO}_{2}$ following cryogenic drying. The database offers records that may be compared to similar records from Cape Grim that were made by other monitoring groups.

\section{Trends Update}

Although CDIAC probably will not print a hard-copy version of Trends during FY 1997, the updated $\mathrm{CO}_{2}$ chapter is available on-line, and we hope to publish the following chapters on-line soon:

- Temperature (updated). This on-line version of the Trends temperature chapter will contain updates (often through 1995 or 1996) of most of the historical temperature records contained in Trends '93. This chapter and those described below will contain the full suite of information (text descriptions, maps, graphical time series, tabular time series, references, etc.) presented previously in hard copy form. One likely addition will be a time series of temperatures dating back to the early 1900 s from a network of South Pacific stations (provided by J. Salinger, National Institute of Water and Atmospheric Research, Auckland, New Zealand). 
- Precipitation (updated). This on-line version of the Trends precipitation chapter will contain updates (often through 1995 or 1996) of most of the historical precipitation records contained in Trends '93, plus at least two (probably more) additional time series: monthly and annual South Pacific precipitation dating back to the early $1900 \mathrm{~s}$ (provided by J. Salinger, National Institute of Water and Atmospheric Research) and gridded, monthly estimates (1987-present) of global precipitation derived from the Special Sensor Microwave/Imager aboard the Defense Meteorological Satellite Program satellites.

- Methane. This on-line version of the Trends methane chapter will contain updates (often through 1995 or 1996) of most of the historical records contained in Trends ' 93 , plus at least four new atmospheric records. These new records include a new ice core record from Antarctica (contributed by D. M. Etheridge), in situ records from Alert, Northwest Territories, Canada (contributed by D. E. J. Worthy) and Cape Grim, Tasmania (contributed by L. P. Steele), and isotopic ${ }^{13} \mathrm{C}$ records from around the world (contributed by C. M. Stevens).

- Other Trace Gases. This on-line version of the Trends Other trace gases chapter will contain updates (often through 1995 or 1996) of most of the historical records contained in Trends '93, plus at least six new atmospheric and emission records. These new records include a new ice core record from Antarctica (provided by D. M. Etheridge), new halocarbon species records from Climate Monitoring and Diagnostics Laboratory (provided by S. A. Montzka), AGAGE records (provided by R. Prinn et al.), CFC-11 and CFC-12 release estimates from Alternatiave Fluorocarbons Environmental Acceptability Study, and in situ records from Alert, Northwest Territories, Canada (provided by D. E. J. Worthy) and Cape Grim, Tasmania (provided by P. J. Fraser).

We also plan to have new issues of our newsletter, CDIAC Communications, and the final issue in the DOE Research Summary series available on-line during FY 1997. Look for these on the CDIAC home page (http://cdiac.esd.ornl.gov), or request printed copies if you prefer them and are not already on our mailing list. Also look for enhancements in both the appearance and the functionality of the CDIAC and GCDIS home pages. 



\section{Other Publications, Presentations, and Awards}

\section{Publications}

Andres, R. J., G. Marland, T. Boden, and S. Bischof. 1996. Carbon dioxide emissions from fossil fuel consumption and cement manufacture 1751-1991; and an estimate of their isotopic composition and latitudinal distribution. In T. Wigley and D. Schimel (eds.), Global Change Institute, Aspen, Colorado. Cambridge University Press, Cambridge, U.K. (in press).

Boden, T. A., G. Marland, and R. J. Andres. 1996. $\mathrm{CO}_{2}$ emission calculations and trends. pp. 18-34. In Proceedings of the 1995 Symposium on Greenhouse Gas Emissions and Mitigation Research, June 27-29, 1995.

Environmental Protection Agency, Washington, D.C.

Cushman, R. M., T. A. Boden, S. B. Jones, T. R. Nelson, and F. W. Stoss. 1996. Carbon Dioxide Information Analysis Center and World Data Center-A for Atmospheric Trace Gases: Fiscal year 1995 annual report. ORNL/CDIAC-89. Oak Ridge National Laboratory, Oak Ridge, Tenn.

\section{Presentations}

Boden, T. A. 1995. "The Carbon Dioxide Information Analysis Center's Ocean-related Data Management Activities." Intergovernmental Oceanographic Commission Data Subpanel Meeting on $\mathrm{pCO}_{2}$. Paris, France, November.

Boden, T. A. 1996. "Trends in Atmospheric Trace Gases and Related Species." Montana Consortium Lecture Series, Oak Ridge, Tenn., March.

Boden, T. A. 1996. "Status Report on CDIAC Data Management Activities in Support of the DOE Ocean $\mathrm{CO}_{2}$ Survey." 13th DOE $\mathrm{CO}_{2}$ Survey Science Team Meeting, Gaithersburg, Maryland, August.

Boden, T. A. 1996. "Oceanographic Data Activities of the Carbon Dioxide Information Analysis Center and World Data Center-A for Atmospheric Traces Gases." Invited lecture, Tianjin, People 's Republic of China, September.

Boden, T. A. 1996. "Global, Regional, and National Carbon Dioxide Emissions from Fossil-Fuel Consumption and Cement Production with Special Emphasis on Chinese Emissions." Invited Lecture, Tianjin, People's Republic of China, September.

Boden, T. A., and P. Kanciruk. 1995. “Advancing Technology and Data Center Operations.” All World Data Center Conference, Wageningen, The Netherlands, October.

Brenkert, A. L. 1996. "Introducing CDIAC to the AmeriFlux Network." AmeriFlux Network Conference, St. Louis, Mo., October 29-30

Cushman, R. M. 1995. “Greenhouse Gases: Sources and Mitigation.” Plant and Soil Science Lecture, The University of Tennessee, Knoxville, Tenn., November.

Cushman, R. M. 1996. "The Carbon Dioxide Information Analysis Center." NIGEC Interregional Climate Change Conference, Tuscaloosa, Ala., May.

Cushman, R. M. 1996. "Establishing Priorities for Reducing Greenhouse-Gas Emissions." 89th Annual Meeting and Exhibition, Air and Waste Management Association, Nashville, Tenn., June.

Cushman, R. M. 1996. "Data Support for Integrated Assessment Research.” Energy Modeling Forum, Snowmass, Colo., July. 
Kaiser, D. P. 1996. "Changes in Monthly Mean Cloud Amount over China: A Closer Look." The Eighth Meeting on Collaborative Research between the People's Republic of China Academia Sinica and the U.S. Department of Energy on $\mathrm{CO}_{2}$-Induced Climate Change, Beijing, China, August 12-14, 1996; The Second Chinese Meteorological Administration/U.S. Department of Energy Science Team Meeting, Beijing, China, August 15-17.

Marland, G., and T. A. Boden. 1996. "CO 2 Emissions: Where We Are and How We Got There." U.S. Global Change Research Program, U.S. Global Change Research Program Seminar Series, Washington, D.C., September 16.

\section{Awards}

CDIAC Communications won a Merit Award for Newsletters in the 1995 Technical Publications and Art Competition sponsored by the East Tennessee Chapter of the Society for Technical Communication. The award was conferred in February 1996.

The DOE Research Summary won an Achievement Award for Newsletters in the same competition.

CDIAC's World Wide Web site (http://cdiac.esd.ornl.gov) was selected as a "3-Star Magellan" site. This designation was based on The McKinley Group's review of the site with regard to the following factors: "Depth: Is it comprehensive and up-to-date? Ease of exploration: Is it well-organized and easy to navigate? Net appeal: Is it innovative? Does it appeal to the eye or the ear? Is it hot, hip, or cool? Is it thought-provoking?" The CDIAC site received three out of a possible four stars. The McKinley Group operates the Magellan Internet directory of 1.5 million sites (http://www.mckinley.com). The star rating appears on the list of "hits" that a user receives in response to a search of the Magellan directory. 


\section{CDIAC Collaborations}

The Carbon Dioxide Information Analysis Center realizes that it would not be possible to produce global-change data and information products without the generosity and cooperation of researchers at institutions throughout the United States and around the world. In this annual report, we have noted the collaborating individuals and institutions for each product. Below are listed the many institutions that have collaborated with CDIAC in the publication of the databases and other information products described in this report.

- Brookhaven National Laboratory

- Commonwealth Scientific and Industrial Research Organisation, Australia

- Connecticut College

- Environmental Protection Agency

- Global Emissions Inventory Centre, Canada

- Institut für Ostseeforschung, Germany

- Institut für Meereskunde, Germany

- Iowa State University

- Lamont-Doherty Earth Observatory of Columbia University

- Lawrence Livermore National Laboratory

- NASA Ames Research Center

- NASA Goddard Institute for Space Studies

- NOAA Climate Monitoring and Diagnostic Laboratory

- NOAA National Climatic Data Center

- Pacific Northwest National Laboratory

- Research Institute of Hydrometeorological Information, Russia

- University of Alaska-Fairbanks

- University of Arizona

- University of Colorado

- University of Florida

- University of Illinois

- University of Washington

- Utah Bureau of Air Quality

- Woods Hole Oceanographic Institution 



\section{Organization and Staff}

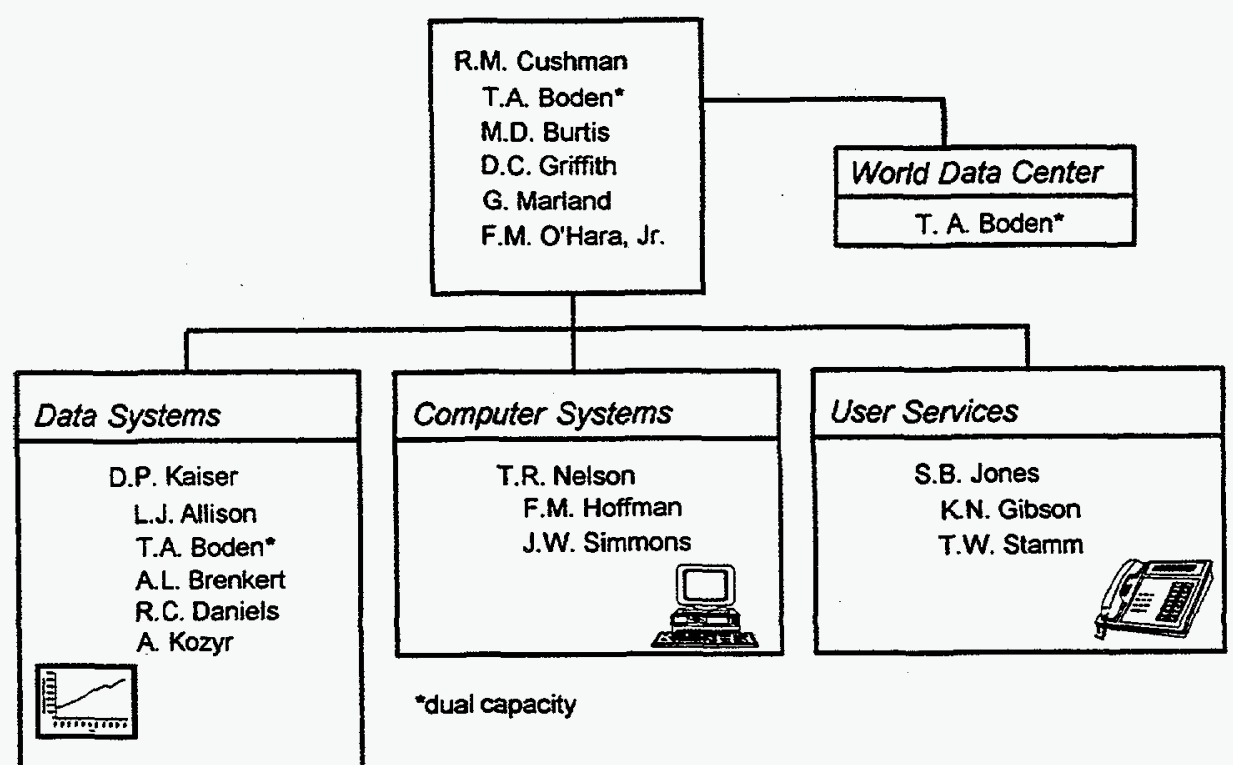

CDIAC staff in FY 1996

\begin{tabular}{|c|c|c|c|}
\hline Staff & $\begin{array}{l}\text { Phone no. } \\
\text { (area code 423) }\end{array}$ & $\begin{array}{l}\text { Internet Address } \\
\text { (@ornl.gov, unless } \\
\text { stated otherwise) }\end{array}$ & Job Title \\
\hline Staff Office & $574-0390$ & cdiac & \\
\hline Linda J. Allison & $576-8449$ & lja & Numeric data analyst \\
\hline Thomas A. Boden & $241-4842$ & tab & $\begin{array}{l}\text { Director, WDC-A for Atmospheric Trace Gases; } \\
\text { Ecologist }\end{array}$ \\
\hline Antoinette Brenkert & $574-7322$ & azt & Ecologist \\
\hline Marvel D. Burtis & $241-4843$ & um6 & Editorial assistant \\
\hline Robert M. Cushman & $574-4791$ & $\mathrm{rma}$ & Director, CDIAC \\
\hline Richard C. Daniels & & & \\
\hline Karen N. Gibson & $241-4854$ & gnk & User Services assistant \\
\hline Dana C. Griffith & $574-0390$ & $\mathrm{xrq}$ & Secretary \\
\hline Forrest M. Hoffman & $576-7680$ & hof & World Wide Web specialist \\
\hline Sonja B. Jones & $574-3645$ & $\operatorname{cdp}$ & Task leader, User Services \\
\hline Dale P. Kaiser & $241-4849$ & $\mathrm{~d} 9 \mathrm{k}$ & Meteorologist; task leader, Global Change Data \\
\hline Alexander V. Kozyr ${ }^{a}$ & $241-4844$ & $\begin{array}{l}\text { alex@utpel033. } \\
\text { ut.edu }\end{array}$ & Oceanographer \\
\hline Gregg Marland & $241-4850$ & gum & Senior scientist \\
\hline Tommy R. Nelson" & $574-0769$ & trn & Task leader, Computer Systems \\
\hline Frederick M. O 'Hara ${ }^{c}$ & $482-1447$ & ffo & Editor, CDIAC Communications \\
\hline James W. Simmons ${ }^{d}$ & $574-1060$ & $\mathrm{~s} 4 \mathrm{i}$ & Workstation specialist \\
\hline Timothy W. Stamm ${ }^{a}$ & $974-8418$ & $\begin{array}{r}\text { tstamm@ } \\
\text { utk.edu }\end{array}$ & Request-response associate \\
\hline
\end{tabular}

"Energy, Environment, and Resources Center, The University of Tennessee, Knoxville.

${ }^{\circ}$ Computational Physics and Engineering Division, ORNL.

'JAYCOR, Oak Ridge, Tenn.

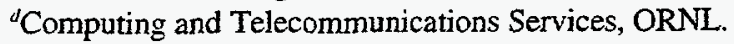

No longer at CDIAC. 



\section{Acronyms and Other Abbreviations}

$\begin{array}{ll}\text { AGAGE } & \text { Advanced Global Atmospheric Gases Experiment } \\ \text { ALE } & \text { Atmospheric Lifetime Experiment } \\ \text { CDIAC } & \text { Carbon Dioxide Information Analysis Center } \\ \text { CFC } & \text { chlorofluorocarbon } \\ \text { DOE } & \text { U.S. Department of Energy } \\ \text { FIP } & \text { File Transfer Protocol } \\ \text { FY } & \text { fiscal year } \\ \text { GAGE } & \text { Global Atmospheric Gases Experiment } \\ \text { HCN } & \text { Historical Climatology Network } \\ \text { NCDC } & \text { National Climatic Data Center } \\ \text { NDP } & \text { numeric data package } \\ \text { NOAA } & \text { National Oceanic and Atmospheric Administration } \\ \text { ORNL } & \text { Oak Ridge National Laboratory } \\ \text { pCO } & \text { partial pressure carbon dioxide } \\ \text { TCO } & \text { total carbon dioxide } \\ \text { WDC-A } & \text { World Data Center-A } \\ \text { WOCE } & \text { World Ocean Circulation Experiment }\end{array}$




\section{Internal Distribution}

$\begin{array}{ll}\text { 1. } & \text { L. J. Allison } \\ \text { 2. } & \text { T. A. Boden } \\ \text { 3. } & \text { M. D. Burtis } \\ \text { 4. } & \text { R. M. Cushman } \\ \text { 5. } & \text { K. N. Gibson } \\ \text { 6. } & \text { S. G. Hildebrand } \\ \text { 7. } & \text { S. B. Jones } \\ \text { 8. } & \text { A. Kozyr } \\ \text { 9. } & \text { G. M. Logsdon }\end{array}$

\author{
10. G. Marland \\ 11. D. E. Shepherd \\ 12. L. D. Voorhees \\ 13. S. J. Wolfe \\ 14. Central Research Library \\ 15-18. ESD Library \\ 19-20. Laboratory Records Dept. \\ 21. Laboratory Records Dept., RC \\ 22. Y-12 Technical Library
}

\section{External Distribution}

23. H. L. Boston, Lockheed Martin Corporation, Hanford, 22950 George Washington Way, Richland, WA 99352

24. P. A. Crowley, Environmental Sciences Division, Office of Health and Environmental Research, ER-74, Department of Energy, 19901 Germantown Rd., Germantown, MD 20874

25. E. C. Cumesty, ORNL Site Manager, Department of Energy, Oak Ridge National Laboratory, P.O. Box 2008, Oak Ridge, TN 37831-6269

26. R. C. Dahlman, Environmental Sciences Division, Office of Health and Environmental Research, ER-74, Department of Energy, 19901 Germantown Rd., Germantown, MD 20874

27. F. A. Donath, Director, Institute for Environmental Education, Geological Society of America, 1006 Las Posas, San Clemente, CA 92673

28. W. Ferrell, Department of Energy, 1000 Independence Ave. SW, Washington, D.C. 20585

29. D. W. Freckman, Director, College of Natural Resources, 101 Natural Resources Building, Colorado State University, Fort Collins, CO 80523

30. J. C. Houghton, Environmental Sciences Division, Office of Health and Environmental Research, ER-74, Department of Energy, 19901 Germantown Rd., Germantown, MD 20874

31. C. Olsen, Office of Health and Environmental Research, ER-74, Department of Energy, 19901 Germantown Rd., Germantown, MD 20874

32. B. Parra, Environmental Sciences Division, Office of Health and Environmental Research, ER-74, Department of Energy, 19901 Germantown Rd., Germantown, MD 20874

33. A. Patrinos, Associate Director, Office of Health and Environmental Research, ER-70, Department of Energy, 19901 Germantown Rd., Germantown, MD 20874

34. M. R. Riches, Office of Health and Environmental Research, ER-74, Department of Energy, 19901 Germantown Rd., Germantown, MD 20874

35. G. S. Sayler, Professor, The University of Tennessee, Center for Environmental Biotechnology, 676 Dabney Hall, Knoxville, TN 37996-1605

36. Energy Library (HR-832.1/GTN), Department of Energy, Office of Administration and Management, G-034, Washington, D.C. 20585

37. Energy Library (HR-832.2/WAS), Department of Energy, Office of Administration and Management, GA-138 Forrestal Building, Washington, D.C. 20585

38. Office of Assistant Manager for Energy Research and Development, Department of Energy Oak Ridge Operations, P.O. Box 2001, Oak Ridge, TN 37831-8600

39-40. Office of Scientific and Technical Information, P.O. Box 62, Oak Ridge, TN 37831 